\title{
Nutritional follow-up of cystic fibrosis patients: the role of nutrition education
}

\author{
Seguimento nutricional de pacientes com fibrose cística: papel do aconselhamento nutricional \\ Fabíola V. Adde, ${ }^{1}$ Joaquim C. Rodrigues, $^{1}$ Ary L. Cardoso ${ }^{2}$
}

Nota: a versão completa deste artigo em português está disponível em www.jped.com.br

\begin{abstract}
Objective: To evaluate the nutritional status of a group of cystic fibrosis patients and establish the role of nutrition education addressed to them in a comparative study before and after intervention.

Methods: All cystic fibrosis patients in regular follow-up in the pulmonology clinic of Instituto da Criança during 1996-99 were prospectively monitored for 3.5 years. Measurements of weight, height, mid upper arm circumference, skinfolds and calculations of weight/age, height/age, weight/height, mid upper arm circumference and triceps z scores, percentage of ideal weight for height, percentage of body fat, check of the use of enzymes with meals and of the use of nutritional supplements were performed at four points in time: initial (I), 7 (II), 13 (III) and 43 (IV) months after the first evaluation. Nutritional counseling was given both verbally and in writing (booklet) to all patients.

Results: Seventy-four patients, 38F/36M, age range 6 months to 18.4 years were evaluated. At study entry the anthropometric data showed: percentage of ideal weight for height $=94 \pm 13$, percentage of body fat $=15 \pm 7.1, \mathrm{z}$ scores for weight/age $=-1.13 \pm 1.3, \mathrm{z}$ scores for height/age $=-0.94 \pm 1.2, z$ scores for weight/height $=-0.69 \pm 1.1$, $z$ scores for mid upper arm circumference $=-1.35 \pm 1.3$, triceps $z$ scores $=-0.74 \pm 0.9$. Compliance with enzyme therapy and use of high-calorie supplements improved during the study period. There was a significant increase in weight/height and triceps z scores and percentage of body fat throughout the study period. After stratifying patients into three age groups the anthropometric improvement was only significant among children under 5 years of age.

Conclusions: Mild malnutrition was present in this group of cystic fibrosis patients. The nutrition education led to an improvement in compliance with enzyme therapy, use of nutritional supplements and in nutritional status, mostly among the younger patients.
\end{abstract}

J Pediatr (Rio J). 2004;80(6):475-82: Malnutrition, cystic fibrosis, nutritional status, nutrition intervention.

\section{Resumo}

Objetivo: Avaliar o estado nutricional de um grupo de pacientes com fibrose cística e analisar a repercussão do aconselhamento nutricional através de um estudo comparativo pré- e pós-intervenção.

Métodos: Todos os pacientes com fibrose cística em seguimento regular no ambulatório de pneumologia do Instituto da Criança no período de 1996-99 foram prospectivamente acompanhados durante 3,5 anos. Em quatro etapas ( $\mathrm{I}=$ inicial, $\mathrm{II}=7$ meses, $\mathrm{III}=13$ meses, IV $=43$ meses), foi realizada uma avaliação nutricional que consistia de medidas de peso, estatura/comprimento, circunferência do braço e pregas cutâneas, e cálculos de escores z para peso/idade, estatura/ idade, peso/estatura, circunferência do braço e da prega cutânea tricipital, porcentagem de peso/estatura e porcentagem de gordura corpórea. Era feita verificação do uso das enzimas pancreáticas e do uso de suplementos nutricionais. Aconselhamento nutricional verbal e através de uma cartilha explicativa foi realizado em todos os pacientes.

Resultados: Foram avaliados 74 pacientes, 38 do sexo feminino e 36 do masculino, com idades de 6 meses a 18,4 anos. Na etapa inicial, os dados antropométricos revelaram: porcentagem de peso/estatu$\mathrm{ra}=94 \pm 13$, porcentagem de gordura corpórea $=15 \pm 7,1$, escore $z$ peso/idade $=-1,13 \pm 1,3$, escore $z$ estatura/idade $=-0,94 \pm 1,2$, escore $\mathrm{z}$ peso/estatura $=-0,69 \pm, 1$, escore $\mathrm{z}$ circunferência do braço $=-1,35 \pm 1,3$, escore $z$ prega cutânea tricipital $=-0,74 \pm 0,9 . \mathrm{A}$ aderência ao uso de enzimas e suplementos melhorou durante o estudo. Houve um aumento significativo no escore $z$ de peso/idade e da prega tricipital e na porcentagem de gordura corpórea durante todo o período de estudo. Dividindo-se os pacientes em três grupos etários, a melhora antropométrica só foi significativa nos menores de 5 anos.

Conclusões: Desnutrição leve estava presente nesse grupo de pacientes com fibrose cística. $\mathrm{O}$ aconselhamento nutricional realizado possibilitou melhora na aderência ao uso de enzimas pancreáticas e de suplementos nutricionais e no estado nutricional, principalmente nos pacientes de baixa idade.

J Pediatr (Rio J). 2004;80(6):475-82: Desnutrição, fibrose cística, perfil nutricional, intervenção nutricional.

1. MD, PhD. Pulmonology Clinic, Instituto da Criança, Hospital das Clínicas, School of Medicine, Universidade de São Paulo (USP), São Paulo, SP.

2. MD, PhD. Nutrology Clinic, Instituto da Criança, Hospital das Clínicas, School of Medicine, USP, São Paulo, SP.

Manuscript received Mar 29 2004, accepted for publication Aug 112004.

Suggested citation: Adde FV, Rodrigues JC, Cardoso AL. Nutritional follow-up of cystic fibrosis patients: the role of nutrition education. J Pediatr (Rio J). 2004;80:475-82. 


\section{Introduction}

Cystic fibrosis (CF) is a severe autosomal recessive disorder affecting many body systems but mainly the respiratory tract. The importance of nutritional status to the long-term survival and well-being of CF patients is well documented.1,2 However, malnutrition remains an important problem in patients with CF residing in the United States: the weight and height of approximately $20 \%$ of children and adolescents with CF are less than the 5th percentile. ${ }^{3}$ Data from the United Kingdom CF population also shows deficits in both weight and height, mostly in those less than one year and above 10 years old, although an improvement in the nutritional status has occurred relative to previous decades. ${ }^{4}$ The magnitude of this problem may be even worse in developing countries, where there may be an overlap of primary and secondary malnutrition in the CF population.

Inadequate weight gain is hypothesized to be caused by an energy imbalance resulting from chronic respiratory disease, malabsorption of nutrients, anorexia ${ }^{5}$ and increased metabolic rate. 6,7 To offset these energy needs treatment recommendations include an energy consumption of 120 to $150 \%$ of the recommended daily allowance (RDA) for calories and adequate pancreatic enzyme replacement therapy. ${ }^{8-10}$ However, children with CF do not typically meet these treatment requirements. ${ }^{11-13}$

Nutrition education of the CF patient and family, involving nutritional information, correct use of enzymes, positive reinforcement of appropriate eating and use of high-calorie supplements when indicated, may ensure that patients will achieve optimum nutrition therapy. ${ }^{14-16}$

The purpose of the current study was to evaluate the nutritional status of a group of CF patients in regular followup at a specialized CF clinic and to establish the role of nutrition education in their nutritional status. The clinical severity of the disease as measured by the Shwachman score was also correlated with the nutritional status.

\section{Patients and methods}

This cohort consisted of all CF patients in regular follow-up at the outpatient CF clinic at Instituto da Criança of Hospital das Clínicas of Universidade de São Paulo, during the period of 1996-99 and was prospectively monitored for 3.5 years. Cystic Fibrosis diagnosis was confirmed by two abnormal sweat chloride results and/or the presence of two known CF mutations on genetic study. Considering the well-established nutritional approach to CF (counseling, use of high-calorie diet, as well as pancreatic enzyme replacement therapy), randomization of exposure would be considered unethical and so the present study was based on a before and after comparison, where the patient was his (or her) own control.

There was no change to CF care with respect of lung disease treatment, which was maintained as prescribed by the treating physician.

The study was approved by the medical ethics committee of our hospital and informed consent was deemed unnecessary due to the fact that intervention was already considered standard in CF care.

\section{Clinical measurement}

Weight, length/height, mid upper arm circumference (MUAC), skinfold thickness (triceps, biceps, subscapular and suprailiac) measurements were all taken by the principal investigator (FVA). These measurements were compared to the National Center for Health Statistics growth charts ${ }^{17}$ and converted to weight/age (W/A), height/age (H/A), weight/height $(\mathrm{W} / \mathrm{H}) \mathrm{z}$ scores based on age and gender, using the Epi-Info program ${ }^{18}$ or calculated with the $z$ score formula ${ }^{19}$ when the values could not be obtained from the Epi-Info program (z score $=$ Standard's mean value - value of subject / standard deviation (SD) of standard).

MUAC and triceps $z$ scores were also calculated with the z score formula. ${ }^{19}$

Percentage of ideal weight for height $(\% \mathrm{~W} / \mathrm{H})$, as recommended by the US Cystic Fibrosis Foundation Nutrition Consensus Report, was calculated as recommended in Appendix A of the 1992 Consensus report. ${ }^{8}$ Calculation of the body fat was based on Siri's equation [body fat \% of weight $=(4.95 /$ body density - 4.5) x 100], where body density is calculated from age and sex adjusted regression equations according to Durnin \& Rahaman. ${ }^{20}$

In the first year of the study the patients had their anthropometric measurements taken at every visit to the clinic, which usually happens every 2 months at our clinic. The patients included in the study had three to seven evaluations in this first year. From these evaluations, three were selected in order to analyze the study population: the initial, one mid-study and one at the end of the first year. On average these took place 7 and 13 months after the initial evaluation. The final evaluation was performed on average 43 months after the first one. This is the reason why these four points in time ( $\mathrm{I}=$ study entry, II $=7$ months after I, III = 13 months after I and IV $=43$ months after I) were selected for the longitudinal evaluation of this group of patients.

The assessment of disease clinical severity was based on the Shwachman score ${ }^{21}$ and was performed at points I and IV by the treating physician during routine yearly reviews.

Serum albumin values were obtained once in the first year of the study, as this was a routine yearly blood analysis.

All but three patients were pancreatic insufficient. Compliance with enzyme therapy (brand and number of capsules of enzymes taken with each meal and snacks) and use of high-calorie nutritional supplements (homemade or industrialized formulas and volume drunk per day) were checked by a semi-structured interview held on all four occasions.

The indications for high-calorie supplement use were weight and/or height for age below the 10th percentile or $\% \mathrm{~W} / \mathrm{H}<90 \%$ or no weight gain in the past 3 months. A homemade, milk-based supplement consisted of a mixture of: $200 \mathrm{ml}$ whole milk, 3 to $5 \%$ sugar, $5 \%$ corn or soya or canol oil and a $10 \%$ calorie-rich shake mix (chocolate or 
other flavor). The energy content of this formula was of approximately $1.5 \mathrm{kcal} / \mathrm{ml}$. To be considered compliant with supplement use the patient had to take at least one glass per day of this formula (around $240 \mathrm{ml}$ ).

A 24-hour dietary recall and \%RDA calculation was performed by a dietitian in cases where there was a need to estimate the daily energy intake.

All patients were on fat-soluble vitamin supplementation and this was not modified during the study.

\section{Nutritional counseling}

Nutritional counseling consisted of an individual briefing with the CF patient and family in every clinic visit (about every 2 months) in the first year of the study and a final one in the end of the study. This was performed by the same physician. The importance of nutrition in CF was discussed with the patient and family members for about 15 minutes, emphasizing the association between nutritional status and lung disease. General nutrition guidelines, with recommendations on how to eat high-energy foods, with no restriction on the intake of fat were taught and reinforced by both the physician and the dietitian. Adequate administration of pancreatic enzymes, according to the fat content of the meals, was also emphasized and was monitored by checking for normal stool pattern and weight gain at the clinic visit.

A booklet containing the topics listed below was distributed to all patients and families after the first evaluation:

- the relevance of a good nutritional status to CF;

- explanation of the reasons why malnutrition could occur in CF (pancreatic insufficiency, increased energy requirements, decreased appetite in some cases);

- pointing out that normal weight and height can be achieved if enzymes and vitamins are taken and high energy foods, rich in fat, are eaten;

- a list of high energy foods and snacks was supplied;
- informing about the need for the prescription of a highcalorie homemade formula or an industrialized supplement in some cases;

- again pointing out the need to take enzymes with every meal and snack and of not letting enzymes run out;

- any further doubts should be raised and discussed with the physician or dietitian.

\section{Statistical analysis}

Values are expressed as mean \pm standard deviation (SD) unless otherwise stated. Comparisons were performed using profile analysis ${ }^{22}$ for serial measurements, as in analysis of variance. Unpaired Student's $t$ test was used to correlate the Shwachman score with nutritional status and the McNemar test was used to analyze the changes in percentage of enzyme and supplements use. Differences were considered statistically significant if $p<0.05$.

As all CF patients in follow-up at this clinic during the period studied were evaluated, sample size was not calculated (the test power would be $80 \%$ to differentiate approximately $0.5 \mathrm{SD}$ between the means under comparison, accepting an $\alpha$ error of $5 \%$ and considering the 74 patients studied).

\section{Results}

Eighty-seven patients began the study but 13 were excluded due to 11 deaths and two losses of follow-up contact during the study period. Our sample therefore consisted of 74 patients, 38 female and 36 male, age range 6 months to 18.4 years at study entry. Their data at the four points in time studied are shown in Table 1. These values show that this group of CF patients had mild malnutrition. Significant increases in W/A and triceps $z$ score and \% body fat were observed throughout the study period. Weight/height and MUAC z scores improved till sample point III.

Table 1 - Clinical and anthropometric data of 74 cystic fibrosis patients

\begin{tabular}{lccccccc}
\hline Sample point & I & II & III & IV & p1 & p2 & p3 \\
\hline Age (years) & $7.6 \pm 4.6$ & $8.2 \pm 4.6$ & $8.7 \pm 4.6$ & $11.2 \pm 4.6$ & & & \\
Shwachman score & $72 \pm 14$ & - & - & $70 \pm 16$ & - & - & NS \\
\% W/H & $94 \pm 13$ & $95 \pm 13$ & $97 \pm 13$ & $95 \pm 14$ & NS & NS & NS \\
z W/A & $-1.13 \pm 1.3$ & $-0.98 \pm 1.3$ & $-0.82 \pm 1.3$ & $-0.87 \pm 1.3$ & $*$ & $*$ & $*$ \\
z H/A & $-0.94 \pm 1.2$ & $-0.84 \pm 1.2$ & $-0.75 \pm 1.1$ & $-0.75 \pm 1.1$ & NS & NS & NS \\
z W/H & $-0.69 \pm 1.1$ & $-0.58 \pm 1.2$ & $-0.43 \pm 1.1$ & $-0.56 \pm 1.2$ & $*$ & $*$ & NS \\
z MUAC & $-1.35 \pm 1.3$ & $-1.08 \pm 1.2$ & $-0.92 \pm 1.2$ & $-1.09 \pm 1.2$ & $*$ & $*$ & NS \\
z triceps & $-0.74 \pm 0.9$ & $-0.63 \pm 0.8$ & $-0.45 \pm 0.9$ & $-0.43 \pm 0.9$ & $*$ & $*$ & $*$ \\
\% BF & $15.0 \pm 7.1$ & $16.1 \pm 7.4$ & $17.6 \pm 7.4$ & $19.3 \pm 7.9$ & $*$ & $*$ & $*$ \\
\hline
\end{tabular}

p1 = I versus II; $\mathrm{p} 2$ = I versus III; $\mathrm{p3}=$ I versus IV (profile analysis); W/H = weight/height; W/A = weight/age; $\mathrm{H} / \mathrm{A}=$ height/age; $\mathrm{MUAC}=$ mid upper arm circumference; $\mathrm{BF}=$ body fat.

${ }^{*} p<0.05 ; \mathrm{NS}=$ not significant. 
The population was then stratified into three age groups ( $<5,5$ to 10 and $>10$ years old) and their clinical and anthropometric data are summarized in Tables 2, 3 and 4 respectively.

A significant improvement over all anthropometric data was observed only in the youngest group (Table 2 ).

Concerning the energy intake, at sample points I, II, III and IV of the study, a total of 50, 42, 48 and 67 dietary recalls were performed, respectively, by the dietitian (the mean \pm SD of $\%$ RDA calculated for these patients was $124 \pm 42,140 \pm 40,135 \pm 38$ and $114 \pm 28$ respectively). For the statistical analysis, we only included the 20 dietary recalls performed at all four of the study sample points . This showed a decrease in energy intake measured in time IV (Table 5).

Compliance to pancreatic enzyme replacement therapy and high-calorie supplements use increased significantly during the study period (Table 6). This was checked by the principal investigator, by means of an interview performed with each patient and family during the clinic visits at all four of the study sample points and also by the dietitian with some patients. Concerning the means of administering the supplements, most patients received these orally and four patients through a gastrostomy tube. The supplement consisted of a high-calorie homemade milk based formula in the majority of cases and was supplied as a complement to, but not as a substitute for meals.

Serum albumin levels were obtained in 69 patients in the first year of the study with a mean $\pm S D$ value of $4.3 \pm 0.5 \mathrm{mg} / \mathrm{dl}$ (range 3.2 to 5.6 ).

When patients were grouped according to Shwachman score ( $\geq 71$, very mild disease and $\leq 70$, mild to severe disease) a significantly better nutritional status was observed in those with less lung involvement (Table 7). As one of the components of the Shwachman score is nutritional status, we decided to calculate a "modified Shwachman score", removing this component. Even so, there continued to be a significant correlation between nutritional status itself ( $z$ scores) and severity of lung disease, as evaluated by the "modified Shwachman score".

Table 2 - Clinical and anthropometric data for the 22 cystic fibrosis patients less than 5 years old

\begin{tabular}{lccccccc}
\hline Sample point & I & II & III & IV & p1 & p2 & p3 \\
\hline Age (years) & $2.4 \pm 1.3$ & $3.0 \pm 1.3$ & $3.4 \pm 1.3$ & $6 \pm 1.3$ & & & \\
Shwachman score & $74 \pm 13$ & - & - & $79 \pm 13$ & - & - & $*$ \\
\% W/H & $96 \pm 16$ & $99 \pm 14$ & $103 \pm 13$ & $104 \pm 13$ & NS & $*$ & $*$ \\
z W/A & $-1.19 \pm 1.6$ & $-0.86 \pm 1.7$ & $-0.44 \pm 1.5$ & $-0.26 \pm 1.5$ & $*$ & $*$ & $*$ \\
z H/A & $-1.2 \pm 1.5$ & $-0.98 \pm 1.4$ & $-0.61 \pm 0.9$ & $-0.59 \pm 1$ & $*$ & $*$ & $*$ \\
z W/H & $-0.46 \pm 1.2$ & $-0.27 \pm 1.5$ & $-0.05 \pm 1.5$ & $0.15 \pm 1.5$ & NS & $*$ & $*$ \\
z MUAC & $-1.45 \pm 1.8$ & $-0.71 \pm 1.7$ & $-0.33 \pm 1.4$ & $-0.44 \pm 1.5$ & $*$ & $*$ & $*$ \\
z triceps & $-0.86 \pm 1.1$ & $-0.59 \pm 1$ & $-0.24 \pm 1.2$ & $-0.11 \pm 1.3$ & $*$ & $*$ & $*$ \\
\% BF & $14 \pm 6.6$ & $15.4 \pm 6.7$ & $17.5 \pm 6.8$ & $18.1 \pm 7.9$ & $*$ & $*$ & $*$
\end{tabular}

p1 = I versus II; p2 = I versus III; $\mathrm{p} 3=$ I versus IV (profile analysis); W/H = weight/height; W/A = weight/age; $\mathrm{H} / \mathrm{A}=\mathrm{height} / \mathrm{age}$; $\mathrm{MUAC}=$ mid upper arm circumference; $\mathrm{BF}=$ body fat

${ }^{*} \mathrm{p}<0.05 ; \mathrm{NS}=$ not significant.

Table 3 - Clinical and anthropometric data for the 32, 5 to 10 years old, cystic fibrosis patients

\begin{tabular}{lccccccc}
\hline Sample point & I & II & III & IV & p1 & p2 & p3 \\
\hline Age (years) & $7.4 \pm 1.4$ & $8.0 \pm 1.4$ & $8.5 \pm 1.4$ & $11 \pm 1.4$ & & & \\
Shwachman score & $72 \pm 15$ & - & - & $68 \pm 17$ & - & - & $*$ \\
\%W/H & $96 \pm 10$ & $96 \pm 11$ & $97 \pm 11$ & $94 \pm 12$ & NS & NS & NS \\
z W/A & $-0.99 \pm 1.2$ & $-0.87 \pm 1.2$ & $-0.83 \pm 1.2$ & $-1.02 \pm 1.2$ & NS & NS & NS \\
z H/A & $-0.77 \pm 0.9$ & $-0.71 \pm 1$ & $-0.76 \pm 1$ & $-0.84 \pm 1.2$ & NS & NS & NS \\
z W/H & $-0.71 \pm 1.2$ & $-0.59 \pm 1.1$ & $-0.46 \pm 1.1$ & $-0.84 \pm 1$ & NS & $*$ & NS \\
z MUAC & $-1.2 \pm 1.1$ & $-1.07 \pm 1$ & $-0.99 \pm 1.1$ & $-1.20 \pm 1$ & NS & NS & NS \\
z triceps & $-0.68 \pm 0.8$ & $-0.62 \pm 0.8$ & $-0.48 \pm 0.8$ & $-0.55 \pm 0.7$ & NS & NS & NS \\
\% BF & $13.9 \pm 6.9$ & $15.2 \pm 7.6$ & $16.2 \pm 7.6$ & $18.4 \pm 8.6$ & $*$ & $*$ & $*$ \\
\hline
\end{tabular}

p1 = I versus II; p2 = I versus III; p3 = I versus IV (profile analysis); W/H = weight/height; W/A = weight/age; $\mathrm{H} / \mathrm{A}=$ height/age; MUAC $=$ mid upper arm circumference; $B F=$ body fat.

${ }^{*} p<0.05 ; N S=$ not significant. 
Table 4 - Clinical and anthropometric data for 20 cystic fibrosis patients over 10 years old

\begin{tabular}{lccccccc}
\hline Sample point & I & II & III & IV & p1 & p2 & p3 \\
\hline Age (years) & $13.7 \pm 2.6$ & $14.3 \pm 2.6$ & $14.7 \pm 2.6$ & $17.2 \pm 2.6$ & & & \\
Shwachman score & $70 \pm 13$ & - & - & $64 \pm 16$ & - & - & $*$ \\
\% W/H & $90 \pm 15$ & $88 \pm 12$ & $89 \pm 10$ & $89 \pm 12$ & NS & NS & NS \\
z W/A & $-1.30 \pm 1.1$ & $-1.28 \pm 1.1$ & $-1.22 \pm 1.1$ & $-1.30 \pm 1$ & NS & NS & NS \\
z H/A & $-0.93 \pm 1.2$ & $-0.89 \pm 1.3$ & $-0.89 \pm 1.3$ & $-0.81 \pm 1.2$ & NS & NS & NS \\
z W/H & $-0.90 \pm 0.8$ & $-0.89 \pm 0.7$ & $-0.81 \pm 0.6$ & $-0.89 \pm 0.6$ & NS & NS & NS \\
z MUAC & $-1.49 \pm 0.9$ & $-1.51 \pm 0.9$ & $-1.46 \pm 0.9$ & $-1.62 \pm 0.9$ & NS & NS & NS \\
z triceps & $-0.69 \pm 0.7$ & $-0.71 \pm 0.7$ & $-0.66 \pm 0.7$ & $-0.60 \pm 0.6$ & NS & NS & NS \\
\% BF & $18.0 \pm 7.6$ & $18.4 \pm 7.7$ & $19.8 \pm 7.7$ & $22.3 \pm 6.2$ & $*$ & $*$ & $*$
\end{tabular}

$\mathrm{p} 1=\mid$ versus $\mathrm{II} ; \mathrm{p} 2=\mathrm{I}$ versus $\mathrm{II} ; \mathrm{p} 3=\mathrm{I}$ versus IV (profile analysis); $\mathrm{W} / \mathrm{H}=$ weight/height; $\mathrm{W} / \mathrm{A}=$ weight/age; $\mathrm{H} / \mathrm{A}=$ height/age; MUAC = mid upper arm circumference; $\mathrm{BF}=$ body fat.

${ }^{*} \mathrm{p}<0.05 ; \mathrm{NS}=$ not significant.

Table 5 - Mean energy intake evaluated in 20 patients

\begin{tabular}{lccccccccc}
\hline Sample point & I & II & III & IV & p1 & p2 & p3 & p4 & p5 \\
\hline$\%$ RDA & $131 \pm 47$ & $139 \pm 34$ & $136 \pm 31$ & $107 \pm 22$ & NS & NS & NS & $*$ & $*$ \\
\hline
\end{tabular}

p1 $=$ I versus II; p2 = I versus III; p3 = I versus IV; 4 = II versus IV; 55 = III versus IV (profile analysis); $\mathrm{RDA}=$ recommended daily allowance.

$* \mathrm{p}<0.05 ; \mathrm{NS}=$ not significant.

Table 6 - Percentage of patients on enzyme and high-calorie supplements use

\begin{tabular}{lccccccc}
\hline Sample point & I & II & III & IV & p1 & p2 & p3 \\
\hline Regular enzyme therapy (\%) & 80 & 84 & 94 & 89 & NS & $*$ & NS \\
High-calorie supplements use (\%) & 33 & 49 & 60 & 65 & $*$ & $*$ & $*$ \\
\hline
\end{tabular}

$\mathrm{p} 1=\mathrm{I}$ versus II; $\mathrm{p} 2=\mathrm{I}$ versus III $; \mathrm{p} 3=\mathrm{I}$ versus IV (McNemar test).

$* \mathrm{p}<0.05 ; \mathrm{NS}=$ not significant.

\section{Discussion}

The nutritional problems with CF are multifactorial. Severity of lung disease, anorexia, pancreatic insufficiency and intestinal and biliary complications contribute to increased energy needs, inadequate intake and excessive nutrient losses.

Our interest in conducting this study arose from the lack of data concerning the nutritional status of CF patients in Brazil and also the need to verify whether a simple intervention program could improve the nutritional status of this CF population.
The results revealed that this group of patients had mild malnutrition with mean W/A and $\mathrm{H} / \mathrm{A} \mathrm{z}$ scores at study entry of $-1.13 \pm 1.3$ and $-0.94 \pm 1.2$, respectively. These results are similar to those obtained by Lai et al., 23 evaluating 13,116 North American CF patients ( 0 to 18 years old) who showed a mean weight/age and height/ age $z$ scores of $-0.74 \pm 1.1$ and $-0.81 \pm 1.2$ respectively. At the end of the study the values found in our study were closer to those of North America, indicating that nutritional status in CF may be quite similar, independently of the development of the country, and relates mostly to the pathophysiology of the disease itself. 
Table 7 - Shwachman score versus nutritional status

\begin{tabular}{lccc}
\hline Shwachman score & $\begin{array}{c}\geq \mathbf{7 1} \\
\mathbf{8 4} \pm \mathbf{8}\end{array}$ & $\mathbf{5 8} \pm \mathbf{9 0}$ & $\mathbf{p}$ \\
\hline $\mathrm{N}^{+}$ & 39 & 48 & \\
Age (years) & $7.2 \pm 4.5$ & $8.9 \pm 5.1$ & \\
$\%$ W/H & $101 \pm 12$ & $87 \pm 12$ & $*$ \\
z W/A & $-0.21 \pm 1.3$ & $-2.03 \pm 0.9$ & $*$ \\
z H/A & $-0.26 \pm 0.9$ & $-1.66 \pm 1.2$ & $*$ \\
z W/H & $-0.04 \pm 1.2$ & $-1.33 \pm 0.8$ & $*$ \\
z MUAC & $-0.49 \pm 1.1$ & $-2.12 \pm 1.1$ & $*$ \\
z triceps & $-0.23 \pm 1.1$ & $-1.21 \pm 0.6$ & $*$ \\
$\%$ BF & $19.1 \pm 6.1$ & $11.7 \pm 6.9$ & $*$ \\
\hline
\end{tabular}

Shwachman score $\geq 71$ versus $\leq 70$ (unpaired Student's $t$ test); $W / H=$ weight/height;

$\mathrm{W} / \mathrm{A}=$ weight/age $; \mathrm{H} / \mathrm{A}=$ height/age $; \mathrm{MUAC}=$ mid upper arm circumference; $\mathrm{BF}=$ body fat

* $p<0.05$

† All 87 patients evaluated at study entry are included.

Despite the chronic malnutrition of many patients, the mean percentage values for ideal weight for height $(\% \mathrm{~W} / \mathrm{H})$ and $\mathrm{W} / \mathrm{H} \mathrm{z}$ scores were within the normal range, showing that in this situation these indices may not be appropriate and should not be used in isolation to evaluate the nutritional status.

The body mass deficit in CF patients usually derives from both body fat and fat-free compartments, including a deficit in muscle mass. This is related to a marked increase in muscle protein catabolism that occurs in CF. ${ }^{24}$ Furthermore, protein synthesis may be decreased during an acute exacerbation of pulmonary infection, also adversely affecting protein-energy balance and protein deposition. ${ }^{24} \mathrm{~A}$ more prominent deficit of fat-free mass compared to the fat compartment (mean MUAC and triceps skinfold $z$ scores of $-1.35 \pm 1.3$ and $-0.74 \pm 0.9$ respectively) was observed in the population studied. Despite that, mean serum albumin levels were within the normal range, showing that they may not correlate well with body composition references.

Nutritional counseling led to an improvement in W/A and triceps skinfold $z$ scores and \% body fat. When patients were stratified into age groups an improvement in all anthropometric data was only observed in those below 5 years of age. This reinforces the hypothesis that malnutrition can be prevented or reverted by early diagnosis and early nutrition therapy, which includes a high-calorie diet, pancreatic enzyme replacement therapy and vitamin supplementation. 25,26

As randomization of exposure would be considered unethical in this study since there is a standard nutritional approach in CF which is considered to be an important part of CF care, it was not possible to do either a placebocontrolled or a crossover study with a washout period. It is very difficult to determine if some of the improvement in nutritional status observed would have occurred despite the nutrition education program. Indeed, some of the improvement in anthropometry seen mostly in the younger children may be due to the catch-up growth that many children with CF have soon after diagnosis and institution of standard care and not only be related to the CF nutrition education program itself.

The nutritional status of children over 10 years of age was most affected. These children have an accelerated linear growth demanding an increase in their energy requirements. In this age group there may be decreased compliance to enzyme therapy and use of high-calorie supplements. Changes in diet and an increase in physical activity also usually occur. Approaches that are appealing and meaningful for them, while focusing on physical appearance, activity and stimulating self-management should be created. ${ }^{15}$

A number of studies of CF patients show a close correlation between the severity of malnutrition and accelerated decline in pulmonary function, which adversely affects overall survival. Conversely, the prevention and treatment of malnutrition is associated with improved prognosis.1,2, 27-29 In this study, poor nutritional status was correlated with more severe lung disease as measured by the Shwachman score. As nutritional status is one of the components of the Shwachman score, we decided to do a modification of the score, removing this component, so that we could better evaluate the correlation of lung disease itself and nutritional status measured by W/A, $\mathrm{H} / \mathrm{A}$ and $\mathrm{W} / \mathrm{H} \mathrm{z}$ scores. In this modified score only the three components that relate mostly to the degree of lung involvement itself were evaluated: general activity, 
physical examination concerning the presence of signs of chronic lung disease and chest radiographic findings. The maximum possible score was 75 . There continued to be a significant correlation between better nutritional status itself and less lung involvement as evaluated by this "modified Shwachman score", or vice versa.

A 24-hour dietary recall was evaluated in only 20 patients. The mean energy intake was above $120 \%$ of RDA till sample point III of the study. We attribute the decrease in energy intake measured at point IV to a probable inaccuracy in the dietary recall when obtained for only a 24hour period. Although the 24-hour dietary recall has been recommended, at least annually, in the routine nutritional assessment of CF patients, ${ }^{10}$ combining this 24 -hour recall with a 3-day food record may provide a more valid assessment of an individual's intake. ${ }^{14}$

Many nutrition interventions aimed at improving the nutritional status of CF patients have proved to be equally effective. ${ }^{16}$ An increase in energy and fat intake and an improvement in weight in CF patients can be achieved by long-term nutrition intervention, performed by nutritional counseling. ${ }^{14}$ Nutrition and self-management questionnaires for children with CF and their caregivers may be a valuable tool in the clinical setting, so that knowledge deficits can be quickly identified and corrected. 30

Nutrition education for the CF patient and family should be provided at the time of diagnosis and continued as part of the routine therapeutic intervention. The recommendation of a high-energy diet with no restrictions on fat intake, the use of high-calorie supplements when indicated and optimization of enzyme replacement therapy should be emphasized. Such a program is simple and inexpensive and may prevent malnutrition, foster normal growth and weight gain, postpone the use of invasive intervention methods and possibly delay progression of lung disease.

\section{Conclusions}

Mild malnutrition was present in this CF population as has been seen at other centers. Nutrition education performed by means of individual talks with the patient and family, a booklet and with close monitoring of enzyme therapy, highcalorie supplements use and anthropometric measurements led to better compliance to enzyme therapy and high-calorie supplement use and also to an improvement in the nutritional status, mostly among the younger patients.

\section{Acknowledgements}

The authors thank Tatiana Rozov, MD, PhD, for her incentive and helpful suggestions in the study, the dietitians Debora Pereira de Carvalho and Ana Rita de Oliveira Ferreira for performing the 24-hour dietary recalls and the RDA calculations and in helping to manufacture the booklet, the statistician Julia Tisue Fukushima, MSc, for performing the statistical analysis and Cresio Romeu Pereira, MD, PhD and Cláudio Leone, MD, PhD for epidemiology and statistical assistance.

\section{References}

1. Gaskin K, Gurwitz D, Durie P, Corey M, Levison H, Forstner G. Improved respiratory prognosis in patients with cystic fibrosis with normal fat absorption. J Pediatr. 1982;100:857-62.

2. Corey M, McLaughlin FJ, Williams M, Levison H. A comparison of survival, growth and pulmonary function in patients with cystic fibrosis in Boston and Toronto. J Clin Epidemiol. 1988;41:583-91.

3. Cystic Fibrosis Foundation. Patient Registry 2001: Annual Report. Bethesda, MD: Cystic Fibrosis Foundation; 2002.

4. Morison S, Dodge JA, Cole TJ, Lewis PA, Coles EC, Geddes D, et al. Height and weight in cystic fibrosis: a cross sectional study. Arch Dis Child. 1997;77:497-500.

5. Reilly JJ, Edwards CA, Weaver LT. Malnutrition in children with cystic fibrosis: the energy-balance equation. J Pediatr Gastroenterol Nutr. 1997;25:127-36.

6. Girardet JP, Tounian P, Sardet A, Veinberg F, Grimfeld A, Tournier G, et al. Resting energy expenditure in infants with cystic fibrosis. J Pediatr Gastroenterol Nutr. 1994;18:214-9.

7. Zemel BS, Kawchak DA, Cnaan A, Zhao H, Scanlin TF, Stallings VA. Prospective evaluation of resting energy expenditure, nutritional status, pulmonary function, and genotype in children with cystic fibrosis. Pediatr Res. 1996;40:578-86.

8. Ramsey BW, Farrell PM, Pencharz P, and the Consensus Committee. Nutritional assessment and management in cystic fibrosis: a consensus report. Am J Clin Nutr. 1992;55:108-16.

9. Sinaasappel M, Stern M, Littlewood J, Wolfe S, Steinkamp G, Heijerman HGM, et al. Nutrition in patients with cystic fibrosis: a European Consensus. J Cystic Fibrosis. 2002;1:51-75.

10. Borowitz D, Baker RD, Stallings V. Consensus report on nutrition for pediatric patients with cystic fibrosis. J Pediatr Gastroenterol Nutr. 2002;35:246-59.

11. Navarro J, Munck A, Varille V. Energy balance and nutritional support in cystic fibrosis. Pediatr Pulmonol. 1995;20(Suppl 11):74-5.

12. Duff AJ, Wolfe SP, Dickson C, Conway SP. Feeding behaviour problems in children with CF: a comparison with healthy controls. Pediatr Pulmonol. 1998;26(Suppl 17):372.

13. Tomezsko JL, Stallings VA, Scanlin TF. Dietary intake of healthy children with cystic fibrosis compared with normal control children. Pediatrics. 1992;90:547-53.

14. Luder E, Kattan M, Thornton JC, Koehler KM, Bonforte RJ. Efficacy of a nonrestricted fat diet in patients with cystic fibrosis. Am J Dis Child. 1989;143:458-64.

15. Luder E. Self-management of nutrition: intervention with adolescents. Pediatr Pulmonol. 1994;18(Suppl 10):97-8.

16. Jelalian E, Stark LJ, Reynolds L, Seifer R. Nutrition intervention for weight gain in cystic fibrosis: a meta analysis. J Pediatr. 1998; 132:486-92.

17. Hamill PVV, Drizd TA, Johnson CL, Reed RB, Roche AF, Moore WM. Physical growth: National Center for Health Statistics percentiles. Am J Clin Nutr. 1979;32:607-29.

18. Dean AG, Dean JA, Coulombier D, Burton AH, Brendel KA, Smith DC, et al. Epi Info, version 6. A word processing, database and statistics program for epidemiology on microcomputers. Atlanta: Center for Disease Control and Prevention; 1994.

19. Frisancho AR. Anthropometric standards for the assessment of growth and nutritional status. Ann Arbor (MI): The University of Michigan Press; 1993. p. 31-42.

20. Brook CGD. Determination of body composition of children from skinfold measurements. Arch Dis Child. 1971;46:182-4.

21. Shwachman H, Kulczycki LL. Long-term study of 105 patients with cystic fibrosis. Am J Dis Child. 1958;96:6-15.

22. Timm NH. Profile Analysis. In: Timm NH, editor. Multivariate analysis with applications in education and psychology. Monterrey (CA): Brooks/Cole Publishing Company; 1975. p. 444-498.

23. Lai HC, Kosorok MR, Sondel AS, Chen ST, Fitzsimmons SC, Green CG, et al. Growth status in children with cystic fibrosis based on the National Cystic Fibrosis Patient Registry data: evaluation of various criteria used to identify malnutrition. J Pediatr. 1998;132:478-85.

24. Holt TL, Ward LC, Francis PJ, Isles A, Cooksley WGE, Shepherd RW. Whole body protein turnover in malnourished cystic fibrosis patients and its relationship to pulmonary disease. Am J Clin Nutr. 1985;41:1061-6. 
25. Marcus MS, Sondel AS, Farrel PM, Laxova A, Carey PM, Langhough $R$, et al. Nutritional status of infants with cystic fibrosis associated with early diagnosis and intervention. Am J Clin Nutr. 1991;54:578-85.

26. Farrel PM, Kosorok MR, Laxova A, Shen G, Koscik RE, Bruns WT, et al. Nutritional benefits of neonatal screening for cystic fibrosis. N Engl J Med. 1997;337:963-9.

27. Elborn JS, Bell SC. Nutrition and survival in cystic fibrosis. Thorax. 1996;51:971-2.

28. Nir M, Lanng S, Johansen HK, Koch C. Long term survival and nutritional data in patients with cystic fibrosis treated in a Danish centre. Thorax. 1996;51:1023-7.

29. Steinkamp G, von der Hardt H. Improvement of nutritional status and lung function after long-term nocturnal gastrostomy feedings in cystic fibrosis. J Pediatr. 1994;124:244-9.
30. Stapleton DR, Gurrin LC, Zubrick SR, Silburn SR, Sherriff JL, Sly PD. What do children with cystic fibrosis and their parents know about nutrition and pancreatic enzymes? J Am Diet Assoc. 2000;100:1494-1500.

Corresponding author:

Fabiola Villac Adde

Rua Conselheiro Brotero, 1330/21

CEP 01232-010 - São Paulo, SP

Brazil

Phone/fax: +55 (11) 3258.5484

E-mail: fabiva@terra.com.br 